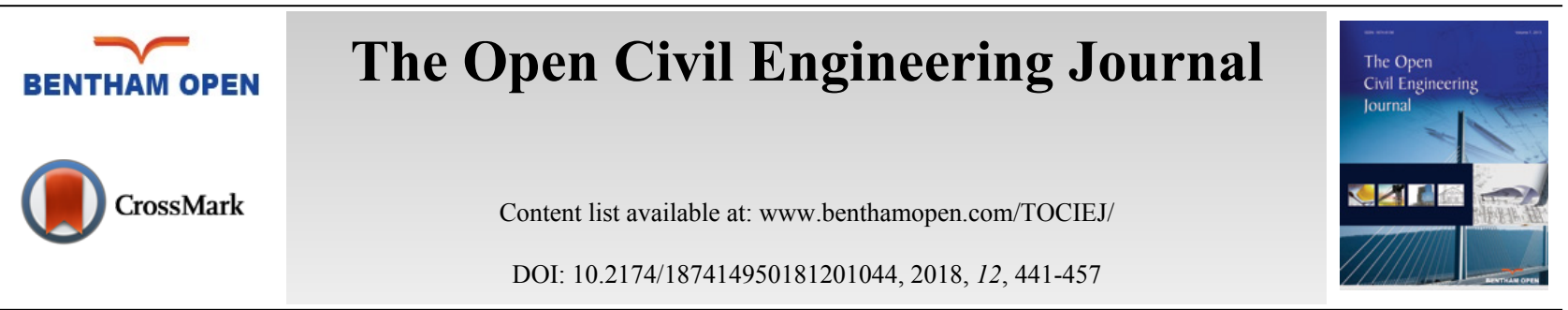

RESEARCH ARTICLE

\title{
Effect of Iron Filings on the Mechanical Properties of Different Types of Sustainable Concrete
}

\author{
Sahar Jabbar Alserai ${ }^{*}$, Wissam Kadhim Alsaraj and Zina Waleed Abass \\ Civil Engineering Department, Al-Mustansiriyah University, Baghdad, Iraq
}

Received: October 8, 2018

Revised: November 14, 2018

Accepted: December 4, 2018

\begin{abstract}
:
Introduction:

One of Iraq's major environmental problems is a large amount of residual iron produced by the industrial sector, which is stored in domestic waste and landfills. The reuse of construction waste gives two aims, the first is to remove large quantities of pollution resulted from these waste, the second provides cheap resources for concrete aggregates.
\end{abstract}

\section{Methods:}

This study conducted a series of experiments and tests to test the feasibility of reusing this iron slag and recycled concrete aggregate in concrete mixtures. Different percentages of iron filings were used in the concrete mixture at $0,0.5 \%, 0.75 \%$ and $1 \%$. Tests are done to evaluate the quality of cast iron concrete which include compressive strength $\left(f_{c u}\right)$, flexural strength $\left(f_{r}\right)$, indirect tensile strength $\left(\mathrm{f}_{\mathrm{t}}\right)$, SEM and modulus of elasticity $(\mathrm{Ec})$ for four sustainable concretes.

\section{Results and Conclusion:}

The results show that the iron filings amount is increased to $1.0 \%$ which resulted in increasing percentage of compressive strength $\left(f_{c u}\right)$, flexural strength $\left(f_{r}\right)$, indirect tensile strength $\left(f_{t}\right)$, SEM and modulus of elasticity $(E c)$ with $10 \%, 32 \%, 42 \%$ and $11 \%$ for Geopolymer Concrete with Recycled Aggregate (GCRA), 9\%, 52\%,31\% and 17\% for geopolymer concrete with natural aggregate (GCNA), 10\%, 19\%,26\% and 12\% for Normal Concrete with Natural Aggregate (NCNA) and 23\%, 19\%, 67\% and 14\% for Normal Concrete with Recycled Aggregate (NCRA), respectively.

Keywords: Geopolymer concrete, Recycled concrete aggregate, Iron filings, Metakaolin, Mechanical properties of geopolymer concrete, Sustainable Concrete.

\section{INTRODUCTION}

In order to solve the global warming problem, some efforts are being made to reduce the use of Portland cement in concrete. These include the use of auxiliary cementing materials such as fly ash, niobium powder, granulated blast furnace slag, rice husk ash and metakaolin, and the development of alternative binders for Portland cement [1]. Davidovits (1988; 1994) assumed that alkaline liquids react with silicon(Si) and aluminum(Al) in geologically derived raw materials or by-product materials such as fly ash and rice husk ash. produce adhesives. Since the chemical reaction that occurs, in this case, is a polymerization process, he coined the term "geopolymer" to represent these binders [1]. Building materials are increasingly influenced by their ecological characteristics. Concrete recycling becomes important because it protects natural resources and eliminates the need for processing by using off-the-shelf concrete as a source of aggregate for new concrete or other applications. Recycling concrete is a relatively simple process. It involves breaking, removing and breaking existing concrete into materials of a specific size and quality [2]. Krishnan and

\footnotetext{
* Address correspondence to this author at the Civil Engineering Department, Al-Mustansiriyah University, Baghdad, Iraq; Tel: +6947706870924; E-mail: saharjabbarcivil@yahoo.com
} 
Purushothaman show that Geopolymer Concrete (GC) containing recycled aggregate concrete can solve major social and environmental problems, such as the consumption of naturally available aggregate sources and the construction and demolition of waste disposal of Landfill [3]. Padmakar and Kumar investidated that the Geopolymer Concrete (GC) based on GGBS and metakaolin has got more compressive strength than conventional concrete and resists the attack of various chemicals and therefore, it is durable for the given mix proportion [4]. Nisreen, Kaiss and Mazin demonstrated that it is possible to recycle concrete waste to achieve high efficiency in reducing cost and environmental impact [5].

\section{OBJECTIVE AND IDEA OF THE CURRENT STUDY}

1. To produce environmentally friendly concrete and eliminate $\mathrm{CO}_{2}$ emissions from $\mathrm{OPC}$.

2. Utilise recycled concrete waste from structure and demolition sites, that would else be disposed of into landfill, as a source of aggregate proposals a potential environmental and economic benefit.

3. The use of iron filings to improve the properties of the Geopolymer concrete helps to reduce the environmental pollution caused by these materials and thus helps the community to get rid of them in a useful way and this is an important part of sustainable engineering.

4. Investigation of mechanical properties of Geopolymer concrete and normal concrete by using recycled concrete aggregate.

\section{EXPERIMENTAL WORK}

Experimental program contains four groups according to the types of concrete; first, group (A) Geopolymer Concrete with Recycled Concrete Aggregate(GCRA), group (B) Geopolymer with Natural Aggregate (GCNA), group (C) Normal Aggregate with Natural Aggregate (NCNA) and group (D) Normal Concrete with Recycled concrete Aggregate (NCRA). Each group includes 12cubes $(100 * 100 * 100) \mathrm{mm}, 4$ prisms $(100 * 100 * 500) \mathrm{mm}$ and 4 cylinders $(100 * 200) \mathrm{mm}$ in addition to 4 of $(150 * 300) \mathrm{mm}$ cylinders. The effect of adding iron filings as a percentage from the volume of concrete mix design has been tested this study. In each case of study, four different percentage of iron filings were used $0 \%$ (control), $0.5 \%, 0.75 \%$ and $1 \%$.

Mix Proportion for GPC based on Basil S., et al (2015) [6] mix with some improvement involved (Table 1).

Table 1. Mix properties of geopolymer concrete.

\begin{tabular}{|c|c|c|c|c|c|c|c|}
\hline Groups & $\begin{array}{c}\text { Iron Filings } \\
\%\end{array}$ & Metakaolin kg/m $\mathbf{m}^{3}$ & Sand $\mathrm{kg} / \mathrm{m}^{3}$ & $\begin{array}{l}\text { Gravel } \\
\mathrm{kg} / \mathrm{m}^{3}\end{array}$ & Alkaline Solution Lit $/ \mathbf{m}^{3}$ & Water Lit $/ \mathbf{m}^{3}$ & $\begin{array}{l}\mathrm{Sp} \\
\%\end{array}$ \\
\hline A,B & $\begin{array}{c}0 \\
0.5 \\
0.75 \\
1.0\end{array}$ & 400 & 720 & 1100 & 180 & 40 & 3 \\
\hline
\end{tabular}

The mix proportion for NC is designed according to ACI recommended Practice ACI 211.1-91 [7], the target compressive strength is $(30 \mathrm{MPa})$ in Table 2.

Table 2. Mix properties of normal concrete.

\begin{tabular}{|c|c|c|c|c|c|c|}
\hline Groups & $\begin{array}{c}\text { Iron Filings } \\
\text { \% }\end{array}$ & Cement $\mathbf{~ k g} / \mathbf{m}^{\mathbf{3}}$ & Sand $\mathbf{~ k g} / \mathbf{m}^{\mathbf{3}}$ & $\begin{array}{c}\mathbf{G r a v e l} \\
\mathbf{~} \mathbf{g} / \mathbf{m}^{\mathbf{3}}\end{array}$ & Water/Cement & $\begin{array}{c}\text { Sp } \\
\mathbf{\%}\end{array}$ \\
\hline \multirow{3}{*}{ C,D } & $\begin{array}{c}0.5 \\
0.75 \\
1.0\end{array}$ & 340 & 780 & 1200 & 0.39 & 3 \\
\hline
\end{tabular}

\section{MATERIALS}

\subsection{Metakaolin}

Metakaolin can also be found by calcining indigenous red clay. The progress of pozzolanic properties in cooked clays depends primarily on the nature and abundance of the clay minerals in the feedstock, the calcination conditions and the fineness of the final product. The calcination temperature resulting from the reaction state is usually in the range from 600 to $800{ }^{\circ} \mathrm{C}$. After heating, recrystallization and formation of $\mathrm{MK}\left(2 \mathrm{SiO}_{2} \mathrm{Al}_{2} \mathrm{O}_{3}\right)$ or mullite $\left(3 \mathrm{Al}_{2} \mathrm{O}_{3} 2_{2} \mathrm{SiO}_{2}\right)$ occur in the reduction of material reactivity. The following section details the metakaolin production process, the chemical 
analysis, physical properties of Metakaolin (Table 3), and Chemical requirements of Pozzolan ASTM C618 [8] (Table 4).

Table 3. Chemical analysis of metakaolin*

\begin{tabular}{|c|c|}
\hline Content, Percent \% & Oxide \\
\hline 54.2 & $\mathrm{SiO}_{2}$ \\
\hline 39.00 & $\mathrm{Al}_{2} \mathrm{O}_{3}$ \\
\hline 0.92 & $\mathrm{Fe}_{2} \mathrm{O}_{3}$ \\
\hline 1.37 & $\mathrm{CaO}$ \\
\hline 0.15 & $\mathrm{MgO}$ \\
\hline 0.45 & $\mathrm{SO}_{3}$ \\
\hline 0.22 & $\mathrm{Na}_{2} \mathrm{O}$ \\
\hline 0.27 & $\mathrm{~K}_{2} \mathrm{O}$ \\
\hline 0.71 & $\mathrm{~L}^{\mathrm{O}} \mathrm{O} . \mathrm{I}$ \\
\hline 0.8 & $\mathrm{TIO}_{2}$ \\
\hline
\end{tabular}

*Chemical tests were conducted by Iraq geological survey, central laboratories department.

Table 4. According to the ASTM C618 [8] chemical requirements of natural pozzolan.

\begin{tabular}{|c|c|c|}
\hline Metakaolin & Pozzolan, Class N & Composition of Oxide \\
\hline 94.12 & 70 & $\mathrm{SiO}_{2}+\mathrm{Al}_{2} \mathrm{O}_{3}+\mathrm{Fe}_{2} \mathrm{O}_{3},(\min \%)$ \\
\hline 0.45 & 4 & $\mathrm{SO}_{3},(\max \%)$ \\
\hline 0.71 & 10 & Loss on ignition, (max \%) \\
\hline
\end{tabular}

\subsection{Cement}

Iraqi common citrate cement (I) (Portland cement I) was used in this study. The cement bag is stored in an airtight plastic container to prevent any moisture. Results analysis of chemical and physical properties of the cement are listed in Tables 5 and 6. The test results show that the cement used is in accordance with IOS No. 5 / 1984 [9]. Tests were made in the building research directorate in Baghdad University.

Table 5. Chemical composition of cement.

\begin{tabular}{|c|c|c|c|}
\hline IQS 5-1984 Limitations of the Normal Cement & By Weight \% & Oxides, Cyclones & Compound Composition \\
\hline---- & 20.37 & $\mathrm{SiO}_{2}$ & Silica \\
\hline---- & 5.15 & $\mathrm{Al}_{2} \mathrm{O}_{3}$ & Alumina \\
\hline---- & 4.39 & $\mathrm{Fe}_{2} \mathrm{O}_{3}$ & Iron Oxide \\
\hline---- & 63.11 & $\mathrm{CaO}$ & Lime \\
\hline Less than $5 \%$ & 1.68 & $\mathrm{MgO}$ & Magnesia \\
\hline Less than $2.8 \%$ & 2.57 & $\mathrm{SO}_{3}$ & Sulfate \\
\hline Less than $4 \%$ & 2.72 & L.O.I & Loss on ignition \\
\hline---- & 1.12 & -- & Free lime \\
\hline 0.66 to 1.02 & 0.92 & L.S.F & Lime saturation factor \\
\hline Less than 1.5 & 0.69 & I.R & Insoluble residue \\
\hline \multicolumn{3}{|c|}{ Main compounds(Bougue's equation) } & \\
\hline & 6.22 & $\mathrm{C} 3 \mathrm{~A}$ & Tricalcium aluminates \\
\hline & 49.23 & $\mathrm{C} 3 \mathrm{~S}$ & Tricalcium silicate \\
\hline & 21.5 & $\mathrm{C} 2 \mathrm{~S}$ & Dicalcium silicate \\
\hline & 13.34 & $\mathrm{C} 4 \mathrm{AF}$ & Tricalcium alumina \\
\hline
\end{tabular}

Table 6. Physical properties of the used cement.

\begin{tabular}{|c|c|c|}
\hline IQS 5/1984 Limitations of Sulphate Resistance Cement & Value & Physical Property \\
\hline$\geq 2300$ & 4426 & Specific Surface Area(cm $\left.{ }^{2} / \mathrm{g}\right)$ \\
\hline$\geq 45$ & 190 & Initial Setting Time(min) \\
\hline$\leq 10$ & $5: 00$ & Final Setting Time(Hours) \\
\hline
\end{tabular}


(Table $\square$ ) contd.....

\begin{tabular}{|c|c|c|}
\hline IQS 5/1984 Limitations of Sulphate Resistance Cement & Value & Physical Property \\
\hline$\geq 15$ & 24 & Compressive Strength 3 days \\
\hline$\geq 23$ & 32 & Compressive Strength 7 days \\
\hline
\end{tabular}

\subsection{Alkaline Solution}

An alkaline liquid mixture of sodium silicate and sodium hydroxide solution was prepared which allowed mixing in the polymerization for a minimum of 24 hours. The sodium silicate solution is commercially available in various grades using a sodium silicate solution $\left(\mathrm{Na}_{2} \mathrm{SiO}_{3}\right)$ and sodium hydroxide $(\mathrm{NaOH})$ having a mass of 3.5. Sodium hydroxide of $97-98 \%$ purity in the form of granules is commercially available. The solid is dissolved in water to make a solution of the desired concentration. Fourteen molar (14M) solutions were used. Since the molecular weight of sodium hydroxide was 40, a 14-molar solution of 14 x $40=560 \mathrm{~g}$ of sodium was prepared. The hydroxide was dissolved in $1000 \mathrm{ml}$ of water. The mass of $\mathrm{NaOH}$ solids in the solution varies depending on the concentration of the solution.

\subsection{Natural Aggregate (NA)}

\subsubsection{Coarse Aggregate}

Natural gravel is used as a coarse aggregate in some mixtures. The results indicate that the coarse aggregate conforms to the Iraqi standard IQS 45-1984 [10] as shown in Tables 7 and 8.

Table 7. Grading of natural coarse aggregate.

\begin{tabular}{|c|c|c|}
\hline Size of Sieve, $\mathbf{m m}$ & \% Passing & Limits of Iraqi Standard IQS No.45-1984 \\
\hline 14 & 100 & $90-100$ \\
\hline 10 & 95 & $85-100$ \\
\hline 5 & 7 & $1-10$ \\
\hline 2.36 & 4 & $0-5$ \\
\hline 1.18 & 0 & $-\cdots-$ \\
\hline
\end{tabular}

*Grading tests were made in the material laboratory, College of Engineering,Al-Mustansiriyah University.

Table 8. Chemical and physical properties of natural coarse aggregate.

\begin{tabular}{|c|c|c|}
\hline Physical Properties & Result of Test & Limits of Iraqi Standard IQS No.45-1984 \\
\hline Specific gravity & 2.6 & --- \\
\hline Absorption, percent & .0 .62 & --- \\
\hline Sulfate content, percent & 0.09 & 0.1 percent maximum \\
\hline
\end{tabular}

*Test was made in the building research directorate in Baghdad University.

\subsubsection{Fine Aggregate}

The natural fine aggregate was used as a part of this work, and should be cleaned before used; the results show that fine aggregate conforms to the Iraqi Standard IQS 45-1984 [10] as shown in Tables 9 and 10.

Table 9. The grading of natural fine aggregate.

\begin{tabular}{|c|c|c|}
\hline Size of Sieve, $\mathbf{~ m m}$ & \% Passing & Limits of Iraqi Standard IQS 45-1984, Zone 2 \\
\hline 10 & 100 & $90-100$ \\
\hline 4.75 & 90.55 & $85-100$ \\
\hline 2.36 & 78.31 & $75-100$ \\
\hline 1.18 & 63.1 & $60-79$ \\
\hline 0.6 & 43.51 & $12-40$ \\
\hline 0.3 & 14.64 & $0-10$ \\
\hline 0.15 & 0.02 & \\
\hline
\end{tabular}

*Grading tests were made in the material laboratory, College of Engineering,Al-Mustansiriyah University. 
Table 10. Chemical and physical properties of natural fine aggregate.

\begin{tabular}{|c|c|c|}
\hline Physical Properties & Test Result & Limits of Iraqi Standard IQS 45-1984 \\
\hline Specific gravity & 2.7 & --- \\
\hline Absorption, percent (\%) & 0.71 & ---- \\
\hline Fineness modulus & 3.1 & --- \\
\hline Sulfate content, percent & 0.36 & 0.5 percent maximum \\
\hline
\end{tabular}

*Test was made in the building research directorate in Baghdad University.

\subsection{Recycled Concrete Aggregates (RCA)}

Recycled concrete is used as a coarse aggregate and fine aggregate in concrete mixes to reduce the environment of gravel and produce inexpensive local concrete. A locally available $12.5 \mathrm{~mm}$ pulverized concrete is used as a coarse aggregate, and a $4.75 \mathrm{~mm}$ is used as the fine aggregate. Recycled aggregates obtained from the demolished construction are used to produce aggregates in the study beams, cubes, cylinders and prisms. The classification of coarse and fine aggregates is in accordance with Iraqi Standard IQS (No. 45/1984) [10]. At first, the stone was broken with a crusher at the Materials Laboratory of the University of Michigan's School of Engineering (Tables 11-14).

Table 11. Grading of recycled coarse aggregate.

\begin{tabular}{|c|c|c|}
\hline Sieve Size, $\mathbf{m m}$ & \% Passing & Limits of Iraqi Standard IQS 45-1984 \\
\hline 14 & 100 & $85-100$ \\
\hline 10 & 94.47 & $0-25$ \\
\hline 5 & 1.66 & $0-5$ \\
\hline
\end{tabular}

*Grading tests were made in the material laboratory, College of Engineering, Al-Mustansiriyah University.

Table 12. The chemical and physical properties of recycled coarse aggregate.

\begin{tabular}{|c|c|c|}
\hline Physical Properties & Test Result & Limits of Iraqi Standard IQS No.45-1984 \\
\hline Density $\left(\mathrm{kg} / \mathrm{m}^{3}\right)$ & 2252 & - \\
\hline Absorption, percent & 0.92 & -- \\
\hline Sulfate content, percent & 0.081 & 0.1 percent maximum \\
\hline
\end{tabular}

Table 13. Grading of recycled fine aggregate.

\begin{tabular}{|c|c|c|}
\hline Size of Sieve, $\mathbf{m m}$ & \% Passing & Limits of Iraqi Standard IQS 45-1984, Zone 2 \\
\hline 10 & 100 & 90 \\
\hline 4.75 & 99.65 & $70-100$ \\
\hline 2.36 & 92.32 & $55-90$ \\
\hline 1.18 & 64.15 & $35-59$ \\
\hline 0.6 & 45.19 & $8-30$ \\
\hline 0.3 & 26.78 & $0-10$ \\
\hline 0.15 & 3.11 & \\
\hline
\end{tabular}

*Grading tests were made in the material laboratory, College of Engineering, Al-Mustansiriyah University.

Table 14. The chemical and physical properties of recycled fine aggregate.

\begin{tabular}{|c|c|c|}
\hline Physical Properties & Test Result & Limits of Iraqi Standard IQS No.45-1984 \\
\hline Density $\left(\mathrm{kg} / \mathrm{m}^{3}\right)$ & 2388 & --- \\
\hline Absorption, percent & 1.1 & --- \\
\hline Fineness modulus & 2.69 & --- \\
\hline Sulfate content, percent & 0.31 & 0.5 percent maximum \\
\hline
\end{tabular}

\subsection{Iron Filings}

The second waste of steel is iron filings, which is produced locally in large quantities in workshops and steel mills. This product has a negative impact on the environment when it is eliminated, for this reason, the research project 
started. Most of the previous investigations referred to steel slag, where one of the few referred to the presentation of iron (Tables 15 and 16).

Table 15. Grading of iron filings.

\begin{tabular}{|c|c|}
\hline $\begin{array}{c}\text { Size of Sieve } \\
\mathbf{~ m m}\end{array}$ & \% Passing \\
\hline 4.75 & 100 \\
\hline 2.36 & 99.32 \\
\hline 1.18 & 87.18 \\
\hline 0.6 & 34.26 \\
\hline 0.3 & 10.3 \\
\hline 0.15 & 3.25 \\
\hline
\end{tabular}

Table 16. Physical properties of iron filings.

\begin{tabular}{|c|c|}
\hline Physical Properties & Test Result \\
\hline Fineness modulus & 2.66 \\
\hline Density $\mathrm{kg} / \mathrm{m}^{3}$ & 7860 \\
\hline Colour & Black-Grey \\
\hline
\end{tabular}

\subsection{Extra Water}

The additional water used in the concrete mix design is the drinking water from the water network system.

\subsection{Distilled Water}

This type is used to dissolve sodium hydroxide to make $\mathrm{NaOH}$ solution.

\subsection{High Range Water Reducing Admixture}

A third-generation geopolymer-based super plasticizer type (F) according to ASTM C494-04 [11], designed for the production of UHPC is used (Glenium 51) in Table 17.

Table 17. Physical Properties of Glenium 51.

\begin{tabular}{|c|c|}
\hline Physical properties & Test Result \\
\hline Relative density & $1.1 @ 20^{\circ} \mathrm{C}$ \\
\hline Form & Viscous Liquid \\
\hline Color & Light Brown \\
\hline $\mathrm{PH}$ & 6.6 \\
\hline Dosage & $(0.5-1.6) \mathrm{L} / 100 \mathrm{~kg}$ of Cement \\
\hline
\end{tabular}

\section{MIXING PROCEDURE}

Aggregate SSD was prepared on a saturated surface in a dry state. The aggregate of recycled concrete (fine aggregate and coarse aggregate) was first mixed in a dry form for 3 minutes in a barrel mixer, then metakaolin (cement) was added and mixed for 2 minutes. Add the alkaline liquid to the geopolymer concrete mixture (add 65\% water), mix the $65 \%$ superplasticizer with the other water for not less than 2 minutes, and then gradually add to the dry material in the mixing tray (65\%). The superplasticizer was mixed with it. $35 \%$ water was added for 5 minutes. Thereafter, an iron filler was added and $35 \%$ of the superplasticizer was added and mixed for 2 minutes. Then, compact the concrete with a vibrating table. In fact, compression requires a lot of skill.

\section{CURING OF SAMPLES}

This method of curing means placing the specimen under direct sunlight outside the laboratory after demolding. Models were poured during temperatures $27^{\circ}$ to $30^{\circ}$, placed models are under the ambient temperature based on previous researches. While normal concrete consisting of ordinary aggregates and recycled concrete aggregates is placed in water basins for 28 days of treatment (Fig. 1). 


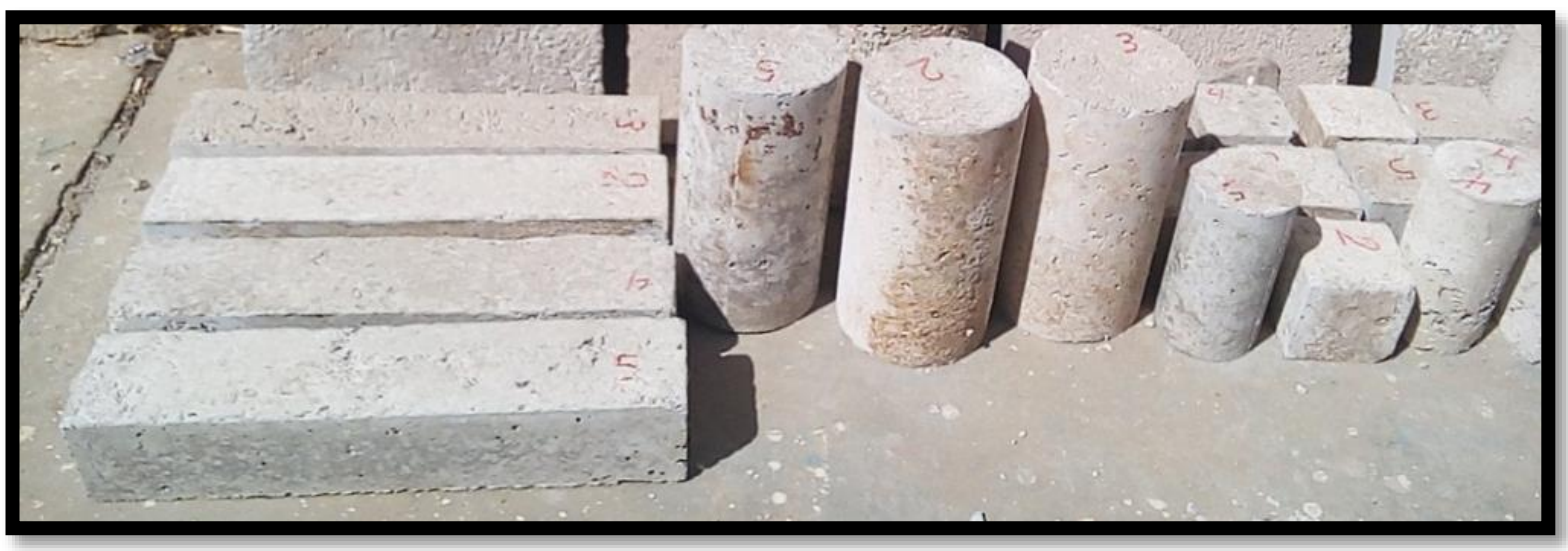

Fig. (1). Curing the samples under direct sunlight.

\section{MECHANICAL PROPERTIES OF CONCRETE}

\subsection{Fresh Properties of Concrete}

\subsubsection{Slump Test}

The slump test was made on fresh Geopolymer and normal concrete immediately after mixing according to the ASTM C143-10a [12]. The slump test results are shown in Fig. (2) and Table 18.

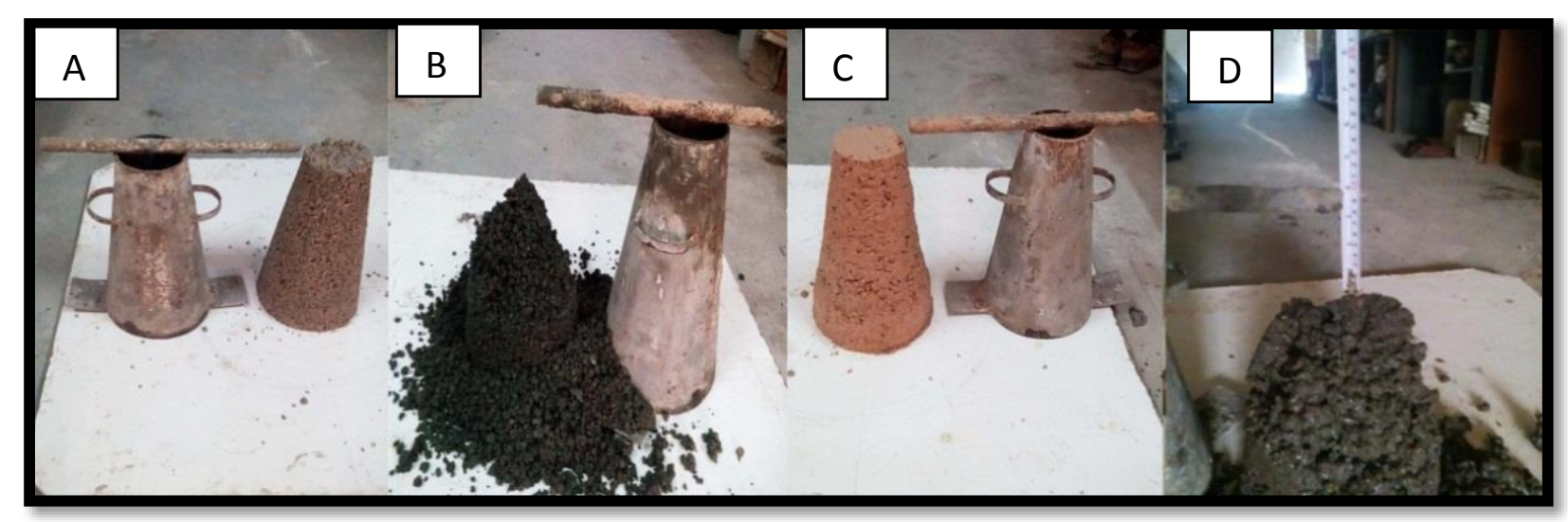

Fig. (2). (A) GPC with recycled concrete aggregate (B) NC with recycled concrete aggregate (C) GPC with normal aggregate (D) NC with normal aggregate.

Table 18. Slump test result.

\begin{tabular}{|c|c|c|c|c|}
\hline Types of Concrete & GCRA & GCNA & NCRA & NCNA \\
\hline Slump result $(\mathrm{cm})$ & 1.5 & 3.5 & 7 & 8 \\
\hline
\end{tabular}

\subsubsection{Setting Time}

Setting time Geopolymer and normal concrete was conducted by using Vicat needle apparatus at room temperature $27^{\circ} \mathrm{C}$ according to the ASTM C 191-08 [13], the test result shown in Fig. (3) and Table 19. 

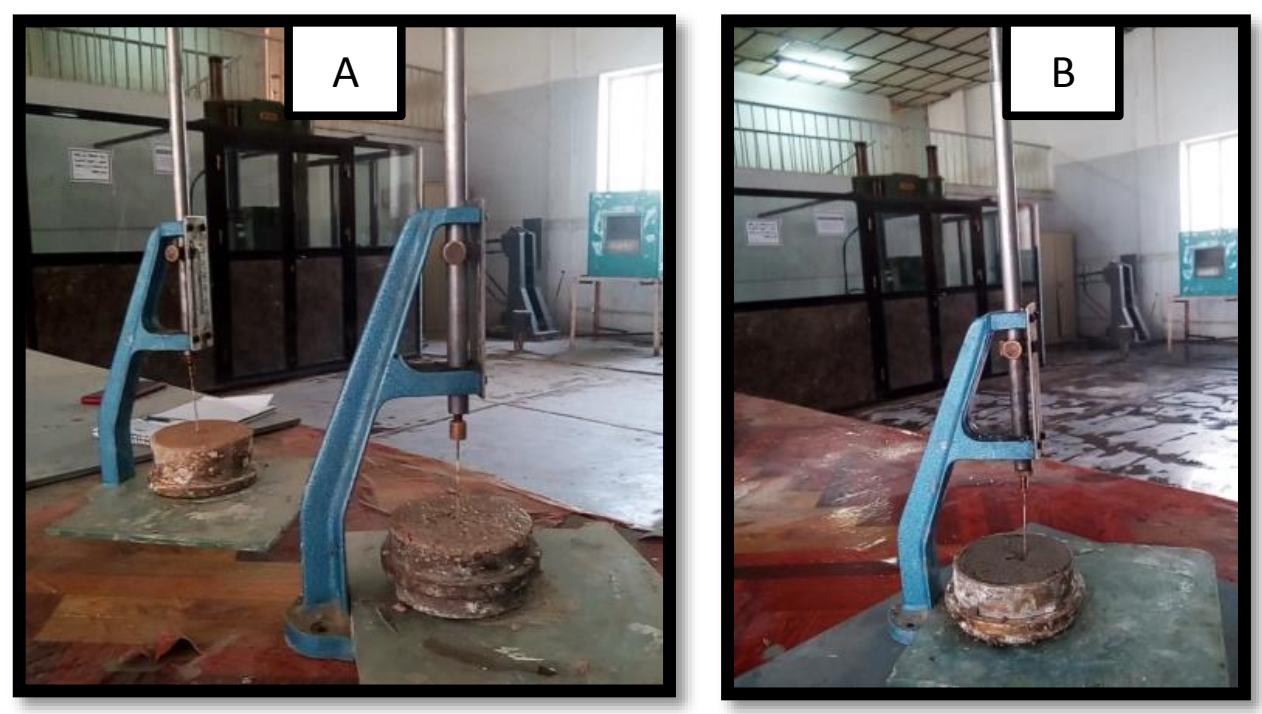

Fig. (3). Vicat apparatus for (A) GCNA and GCRA (B) NCRA.

Table 19. Setting Time result.

\begin{tabular}{|c|c|c|c|c|}
\hline Types of Concrete & GCRA & GCNA & NCRA & NCNA \\
\hline Initial Setting Time(min) & 20 & 30 & 45 & 190 \\
\hline Final Setting Time(min) & 120 & 150 & 450 & 300 \\
\hline
\end{tabular}

According to the slump and sitting time results shown in Tables $\mathbf{1 4}$ and 15, the amount of slump and sitting time of the Geopolymer with the recycled concrete aggregates are less than the amount of slump and sitting time of the natural aggregates due to the presence of the cement which did not dissolve, which caused the withdrawal of the water of the mixture to lead to a lower degree of the compact and thus negatively affect on the compressive strength for mixtures containing recycled concrete aggregates, and thus reducing the workability of the mix.

\subsection{Hardened Properties of Concrete}

Control samples were cast from each mixture to determine the mechanical properties of NC and GPC, including compressive strength (fcu), split tensile strength (fct), modulus of rupture (fr), and modulus of elasticity (Ec). The average of the three samples was considered for each mixture. Table $\mathbf{8}$ shows the properties of hardened concrete.

\subsection{Compressive Strength Test}

The compressive strength test is done with BS. 1881: Part 116: 1989 [14]. Three cubes with dimensions of $100 \times 100 \times 100$ in mms for each mix were tested by using a hydraulic compression machine of $2000 \mathrm{kN}$. The test was carried out at age of 28 days. The result of the compressive strength test was shown in Table 20 and Fig. (4).

Table 20. Properties of hardened GPC and NC.

\begin{tabular}{|c|c|c|c|c|c|c|c|c|c|}
\hline Details & Iron Filings $V_{i} \%$ & $\begin{array}{c}f_{c u} \\
\mathrm{MPa} \\
\end{array}$ & $\begin{array}{c}\text { Increasing } \\
\%\end{array}$ & $\begin{array}{c}f_{s p} \\
\mathrm{MPa} \\
\end{array}$ & \begin{tabular}{|c|} 
Increasing \\
$\%$
\end{tabular} & $\begin{array}{c}f_{r} \\
\mathrm{MPa}\end{array}$ & $\begin{array}{c}\text { Increasing } \\
\%\end{array}$ & $\begin{array}{c}E c \\
\mathbf{G P a}\end{array}$ & $\begin{array}{c}\text { Increasing } \\
\%\end{array}$ \\
\hline \multirow{4}{*}{$\begin{array}{l}\text { GPC recycled concrete aggregate } \\
\text { (A) }\end{array}$} & 0 & 25.9 & -- & 2.65 & -- & 2.54 & -- & 18.8 & -- \\
\hline & 0.5 & 26.5 & 2 & 3.18 & 20 & 3.2 & 26 & 19.2 & 2 \\
\hline & 0.75 & 27.3 & 5 & 3.3 & 25 & 3.35 & 32 & 20.5 & 9 \\
\hline & 1.0 & 28.5 & 10 & 3.51 & 32 & 3.6 & 42 & 20.8 & 11 \\
\hline \multirow{4}{*}{$\begin{array}{l}\text { GPC with natural aggregate } \\
\text { (B) }\end{array}$} & 0 & 30.8 & -- & 3.0 & -- & 3.8 & -- & 20.4 & -- \\
\hline & 0.5 & 31.5 & 2 & 3.78 & 26 & 4.3 & 13 & 21.5 & 5 \\
\hline & 0.75 & 32.5 & 6 & 4.2 & 40 & 4.79 & 26 & 22.1 & 8 \\
\hline & 1.0 & 33.6 & 9 & 4.57 & 52 & 4.962 & 31 & 24.2 & 17 \\
\hline \multirow{4}{*}{$\begin{array}{l}\mathrm{NC} \text { with natural aggregate } \\
\text { (C) }\end{array}$} & 0 & 32.8 & -- & 3.2 & -- & 3.5 & -- & 24.9 & -- \\
\hline & 0.5 & 34 & 4 & 3.5 & 9 & 4.1 & 17 & 25.2 & 1 \\
\hline & 0.75 & 35 & 7 & 3.57 & 12 & 4.23 & 21 & 26.8 & 8 \\
\hline & 1.0 & 36 & 10 & 3.8 & 19 & 4.5 & 26 & 27.8 & 12 \\
\hline
\end{tabular}




\begin{tabular}{|c|c|c|c|c|c|c|c|c|c|}
\hline Details & Iron Filings $V_{i} \%$ & \begin{tabular}{|c|}
$f_{c u}$ \\
MPa \\
\end{tabular} & \begin{tabular}{|c|} 
Increasing \\
$\%$
\end{tabular} & \begin{tabular}{|c|}
$f_{s p}$ \\
MPa \\
\end{tabular} & \begin{tabular}{|c|} 
Increasing \\
$\%$
\end{tabular} & $\begin{array}{c}f_{r} \\
\text { MPa } \\
\end{array}$ & \begin{tabular}{|c|} 
Increasing \\
$\%$ \\
\end{tabular} & \begin{tabular}{|c|}
$E c$ \\
$\mathrm{GPa}$ \\
\end{tabular} & \begin{tabular}{|c|} 
Increasing \\
$\%$
\end{tabular} \\
\hline \multirow{4}{*}{$\begin{array}{l}\mathrm{NC} \text { with recycled concrete aggregate } \\
\text { (D) }\end{array}$} & 0 & 34.1 & -- & 3.9 & -- & 4.1 & -- & 25.1 & -- \\
\hline & 0.5 & 35 & 3 & 4.3 & 10 & 4.9 & 20 & 26.3 & 5 \\
\hline & 0.75 & 39 & 14 & 4.46 & 14 & 5.9 & 50 & 27.7 & 10 \\
\hline & 1.0 & 42 & 23 & \begin{tabular}{|l|}
4.63 \\
\end{tabular} & 19 & 6.85 & 67 & 28.5 & 14 \\
\hline
\end{tabular}
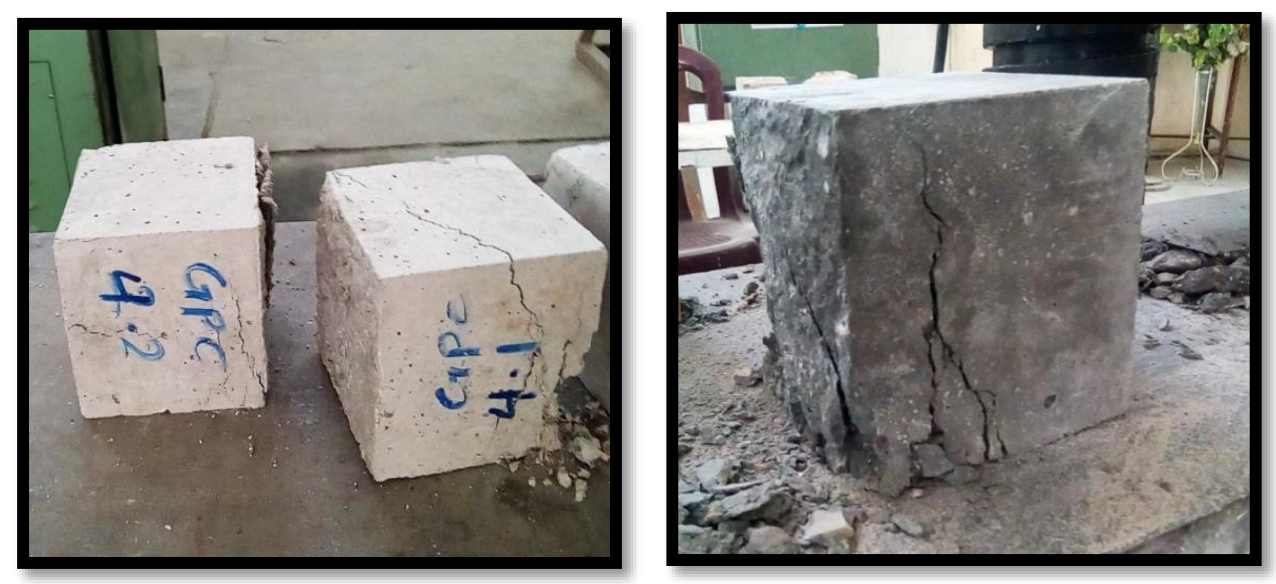

Fig. (4). Compression failure of NC and GPC cubes after failure.

Table 20 and Fig. (5) show that the increase of iron filings from 0 to $0.5 \%, 0.75 \%$, and $1.0 \%$, resulted in increasing percentage of the compressive strength $\left(f_{c u}\right)$, with $2 \%, 5 \%$, and $10 \%$ for Geopolymer Concrete with Recycled Concrete Aggregate (GCRA), 2\%, 6\% and 9\% for Geopolymer Concrete with Natural Aggregate (GCNA), 4\%, 7\% and 10\% for normal concrete with natural aggregate (NCNA), and 3\%, 14\% and 23\% for Normal Concrete with Recycled Concrete Aggregate (NCRA). The maximum value of the compressive strength was 28.5 MPa for GNRA, 33.6 MPa for GCNA, $36 \mathrm{MPa}$ for NCNA and $42 \mathrm{MPa}$ for NCRA occurred with iron filings $1 \%$.

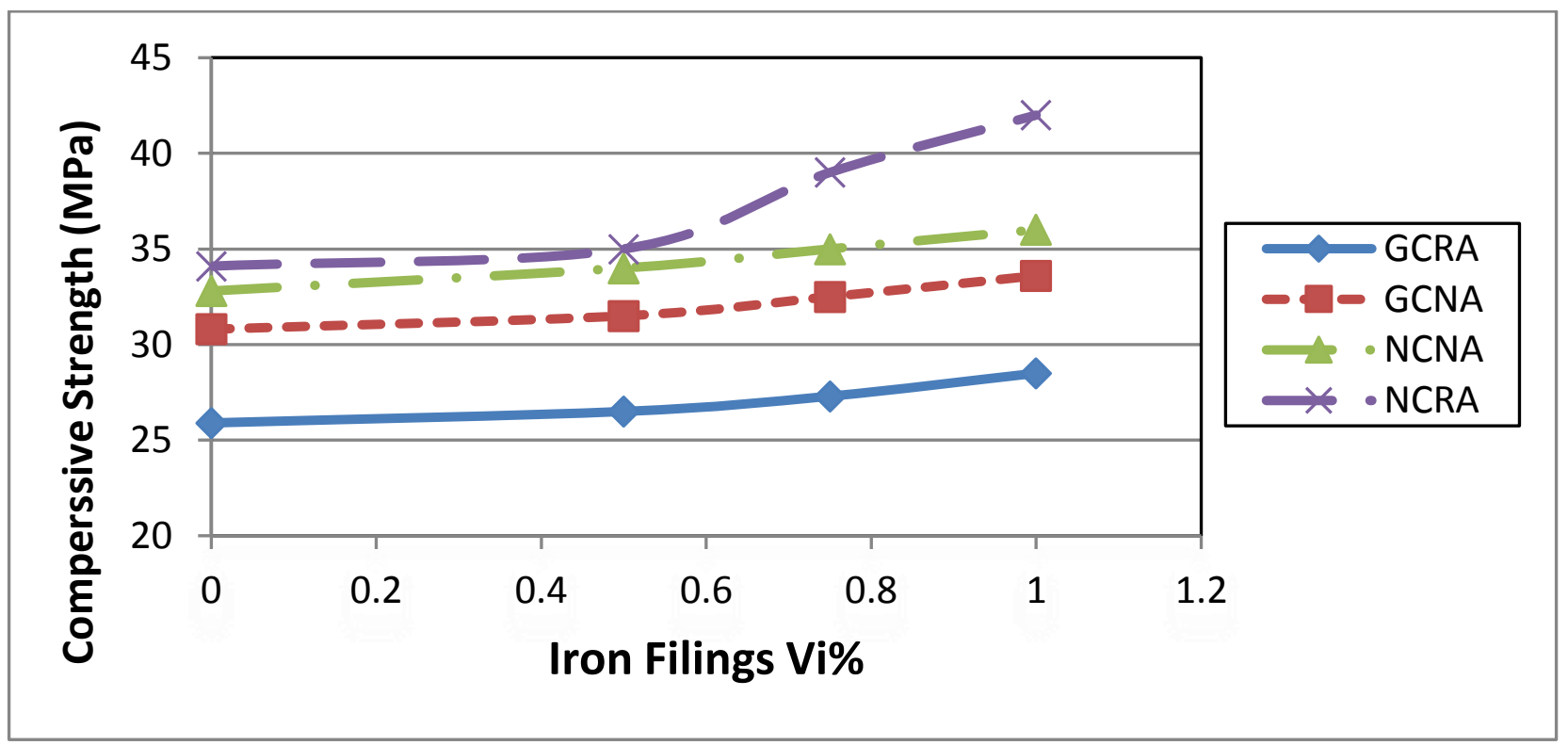

Fig. $]$ contd.... 


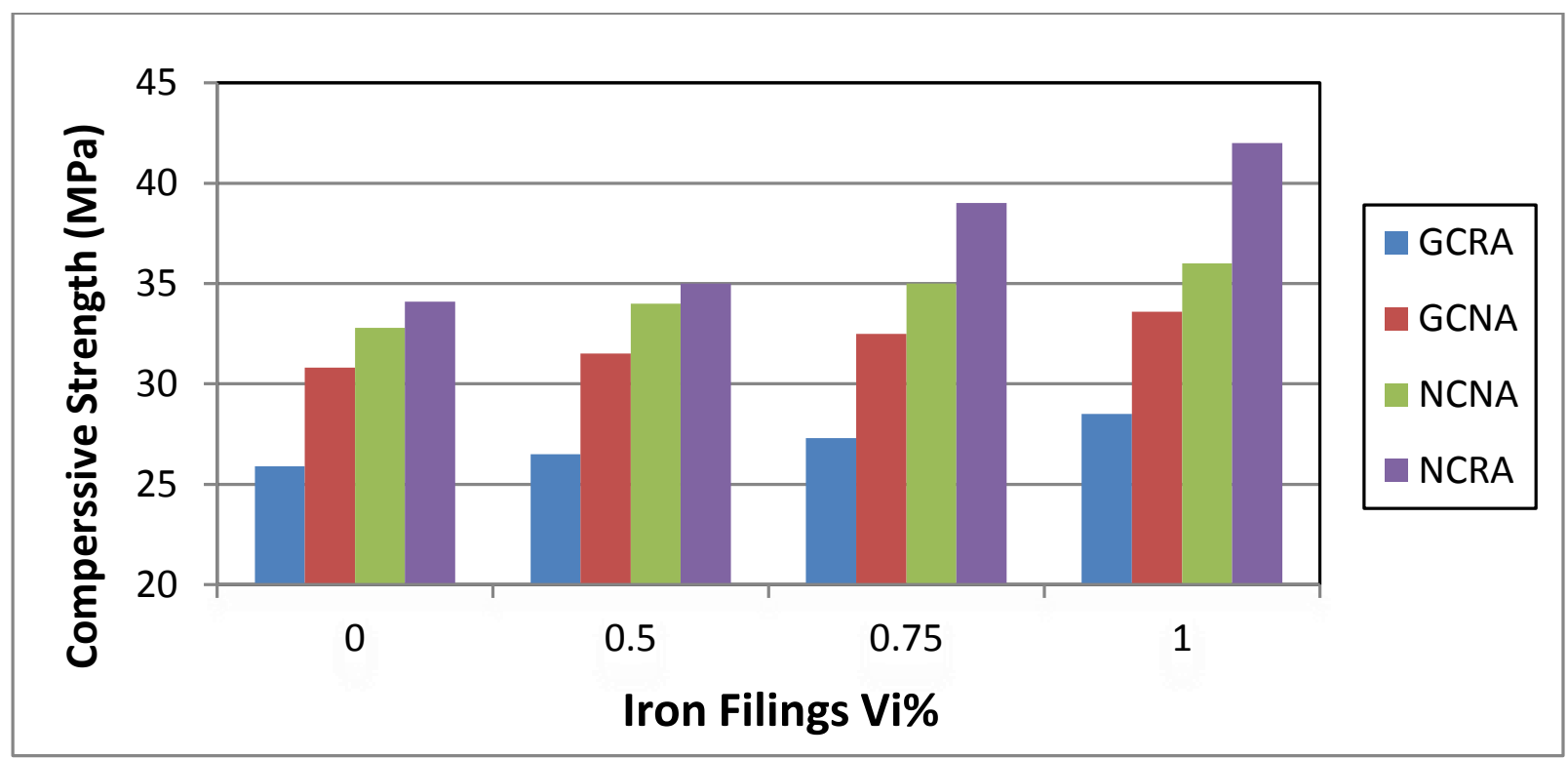

Fig. (5). Iron filings effect on compressive strength

\subsection{Indirect Tensile Strength Test}

The indirect tensile strength is carried out with (ASTM C496-2004) [15] specification and three cylinders of $(100 \times 200) \mathrm{mm}$ for each mix is used. The test conducted by using a hydraulic compression machine of $2000 \mathrm{kN}$. Thin plywood strips are put between the specimen and both the upper and the lower bearing blocks of testing machine. The test involved applying a diametric compressive force along the length of a cylindrical concrete specimen (Fig. 6).
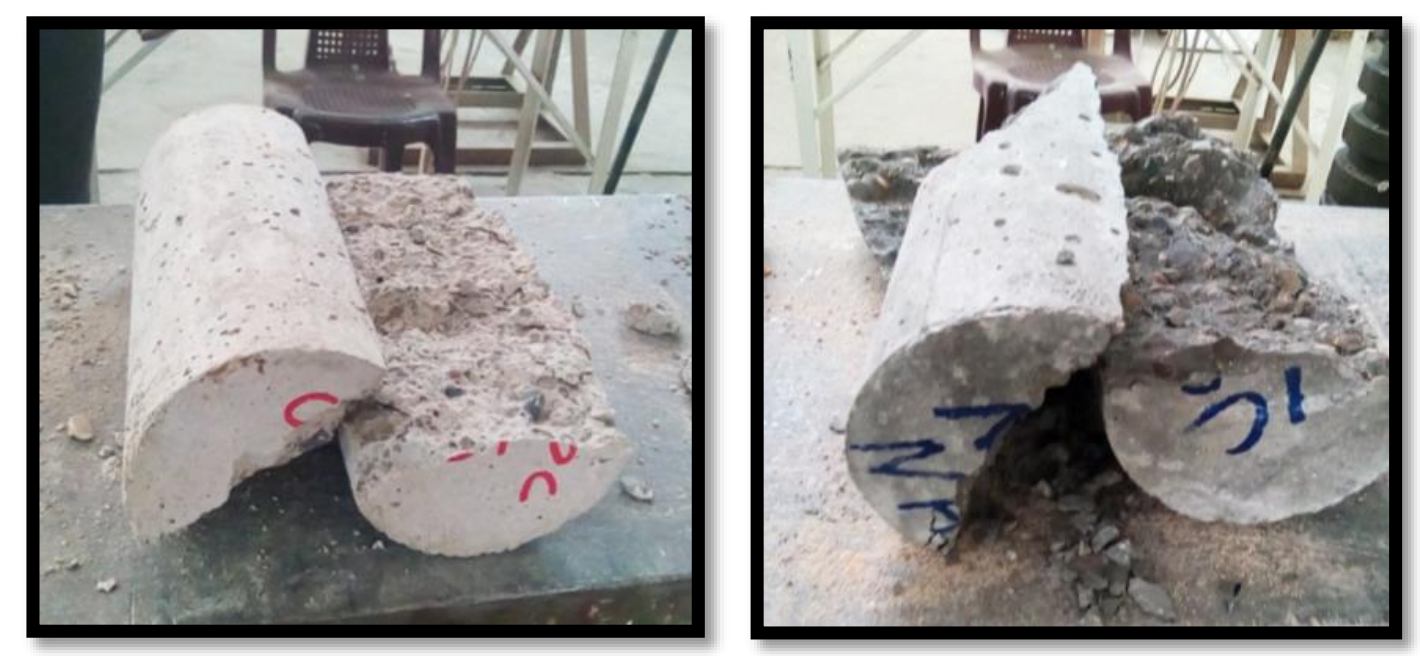

Fig. (6). Splitting failure of NC and GPC cylinders.

Table 20 and Fig. (7) show that an increasing of iron filings from 0 to $0.5 \%, 0.75 \%$, and $1.0 \%$, resulted increasing percentage of the splitting tensile strength with $20 \%, 25 \%$, and $32 \%$ for GCRA, $26 \%$, 40\% and 52\% for GCNA, $9 \%$, $12 \%$ and $19 \%$ for NCNA and $10 \%, 14 \%$ and $19 \%$ for NCRA. The maximum value of the splitting tensile strength was 3.51 MPa for GCRA, 4.57 MPa for GCNA, 3.8 MPa for NCNA and 4.63 MPa for NCRA occurred with iron filings $1 \%$. 

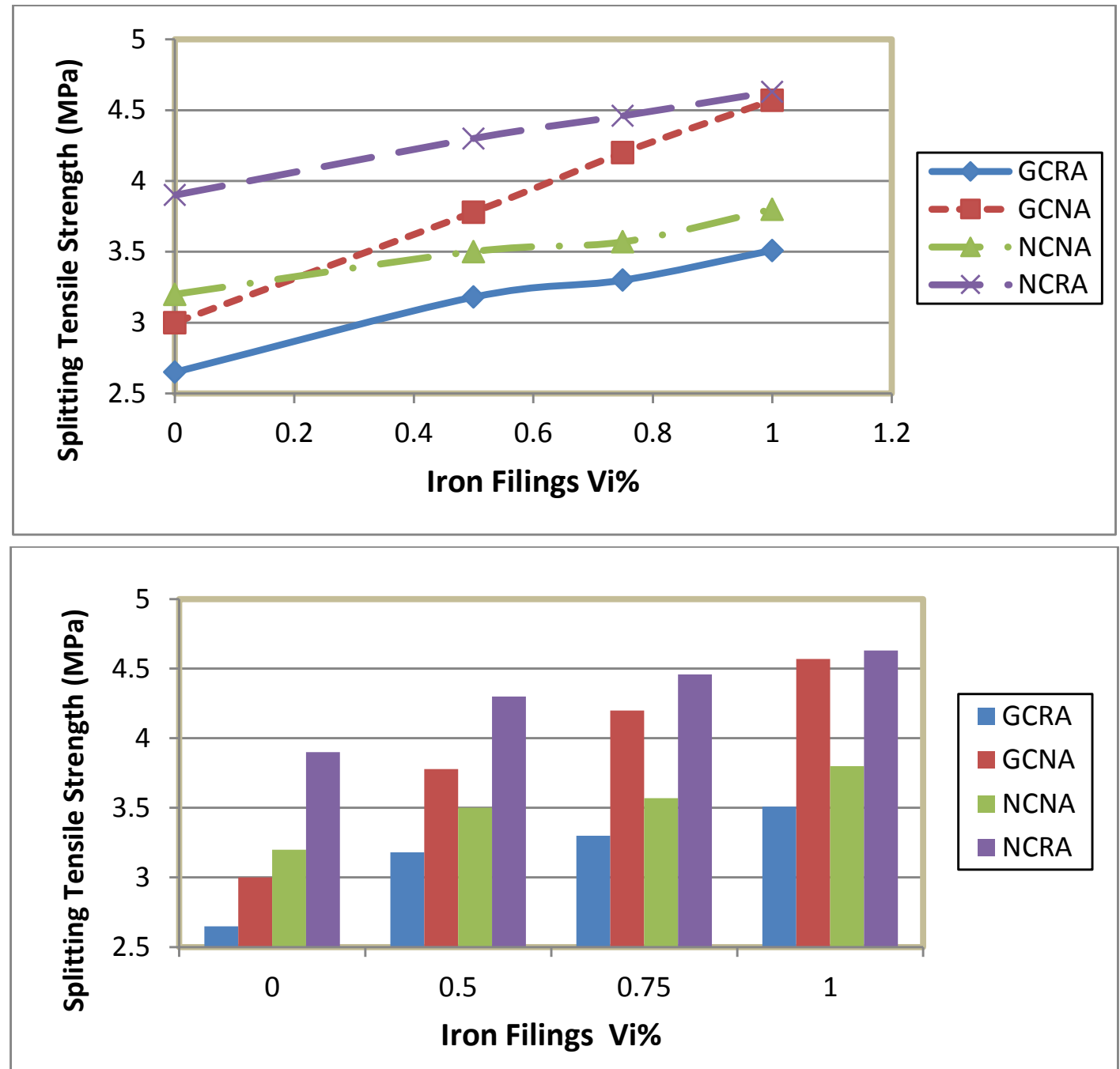

Fig. (7). Iron filings effect on the splitting tensile strength.

\subsection{Flexural Strength Test}

The flexural strength was carried out according to (ASTM C78-2005) [16] with three $(100 \times 100 \times 500) \mathrm{mm}$ prisms used for each mix (Fig. 8).
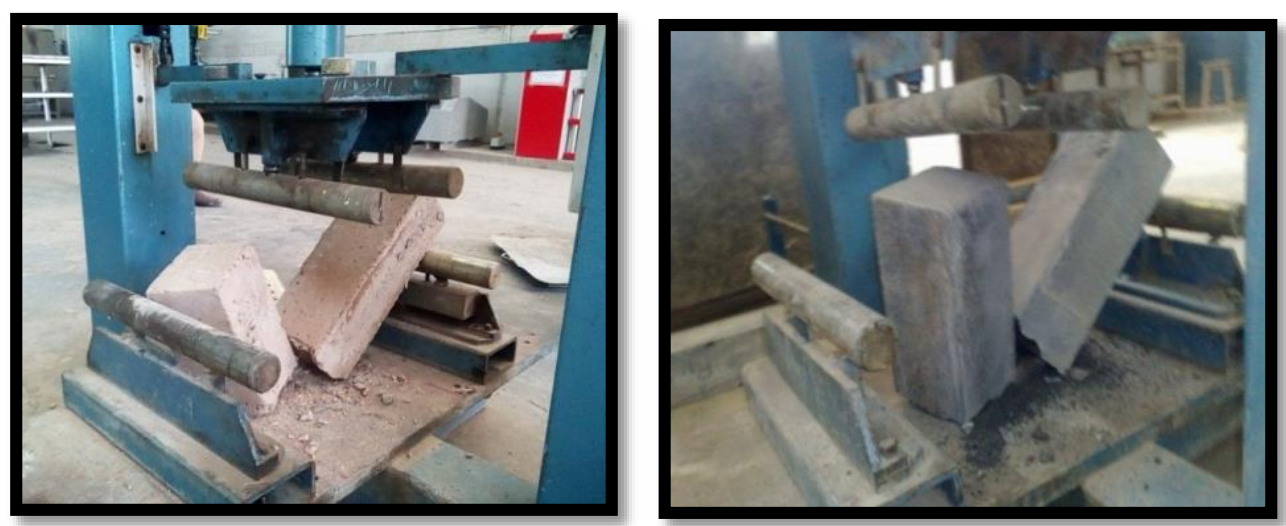

Fig. (8). Modulus of rupture test of NC and GPC prisms. 
Table 20 and Fig. (9) show that an increasing of iron filings from 0 to $0.5 \%, 0.75 \%$,and $1.0 \%$, resulted increasing percentage of the flexural tensile strength with $26 \%, 32 \%$, and $42 \%$ for GCRA, $13 \%, 26 \%$ and $31 \%$ for GCNA, $17 \%$, $21 \%$ and $26 \%$ for NCNA and $20 \%, 50 \%$ and $67 \%$ for NCRA. The maximum value of the flexural tensile strength was 3.6 MPa for GCRA, 4.962 MPa for GCNA, 4.5 MPa for NCNA, and 6.85 MPa for NCRA, occurred with iron filings $1 \%$.
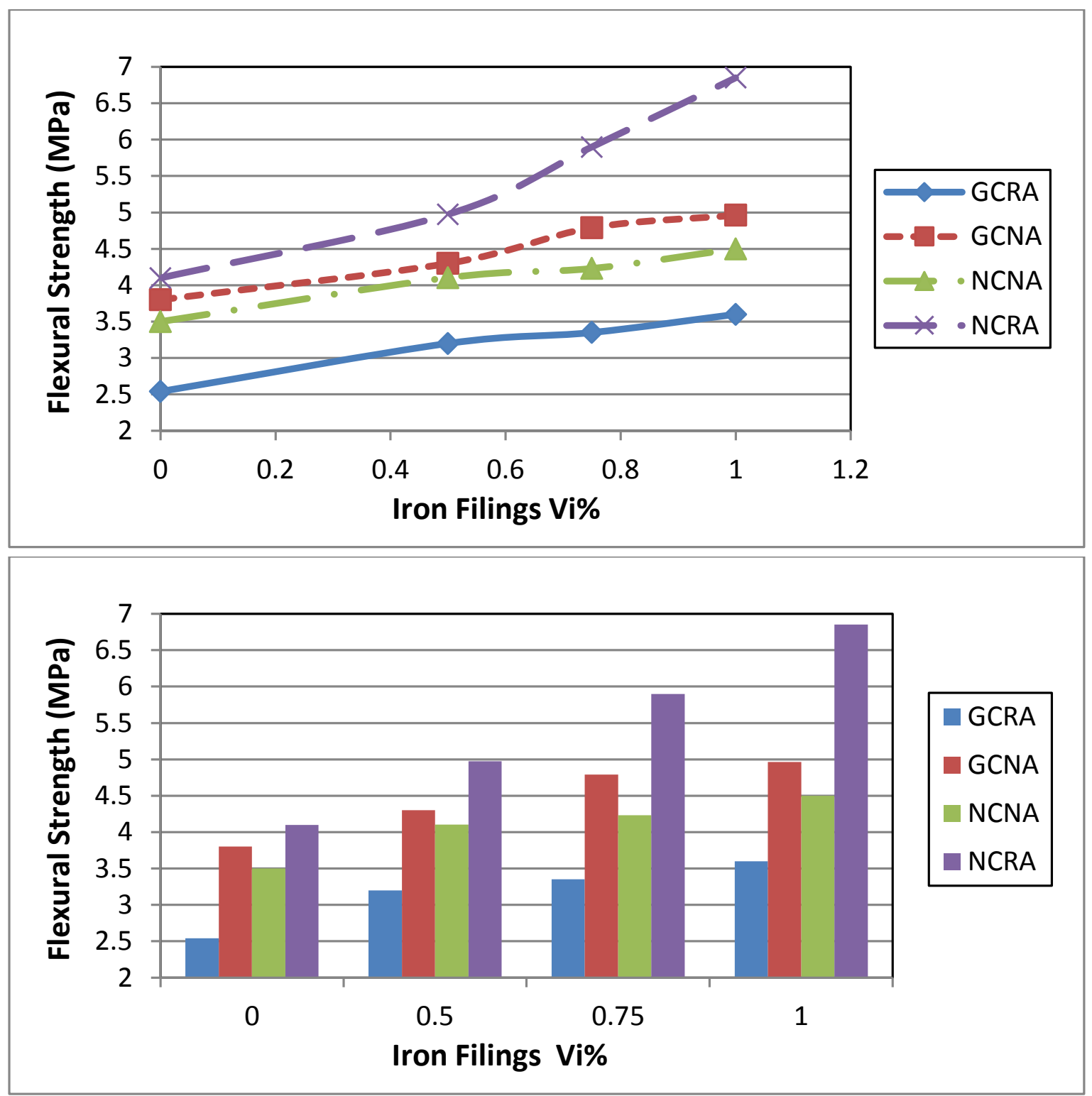

Fig. (9). Iron Filings effect on the flexural tensile strength.

\subsection{Modulus of Elasticity}

Static modulus of elasticity test was performed according to ASTM C469-2002 [17]. This test method provides a stress-strain curve for hardened concrete at whatever age and curing conditions may be designated. The slope of the curve representing the chord modulus is given by the slope of the line from the point representing the longitudinal strain of 50 microstrains to the point corresponding to $40 \%$ of the ultimate load for normal concrete and $30 \%$ of the ultimate load for geopolymer concrete. The three specimen cylinders $(150 * 300) \mathrm{mm}$ for each mix was tested (Fig. 10). 

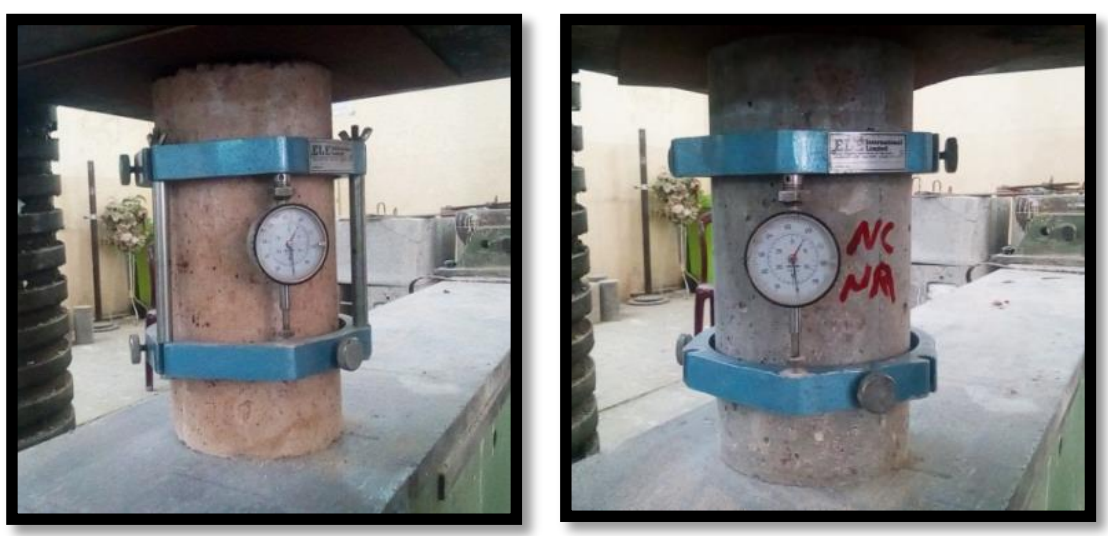

Fig. (10). Modulus of elasticity $\left(E_{c}\right)$ test for NC and GPC cylinders.

Table 20 and Fig. (11) show that an increase of iron filings from 0 to $0.5 \%, 0.75 \%$, and $1.0 \%$, resulted in increasing percentage of the modulus of elasticity with $2 \%, 9 \%$, and $11 \%$ for GCRA, $5 \%, 8 \%$ and $17 \%$ for GCNA, $1 \%, 8 \%$ and $12 \%$ for NCNA and 5\%, 10\% and 14\% for NCRA. The maximum value of the modulus of elasticity was $20.8 \mathrm{MPa}$ GCRA, 24.2 MPa for GCNA, 27.8 MPa for NCNA and 28.5 MPa for NCRA occurred with iron filings $1 \%$.
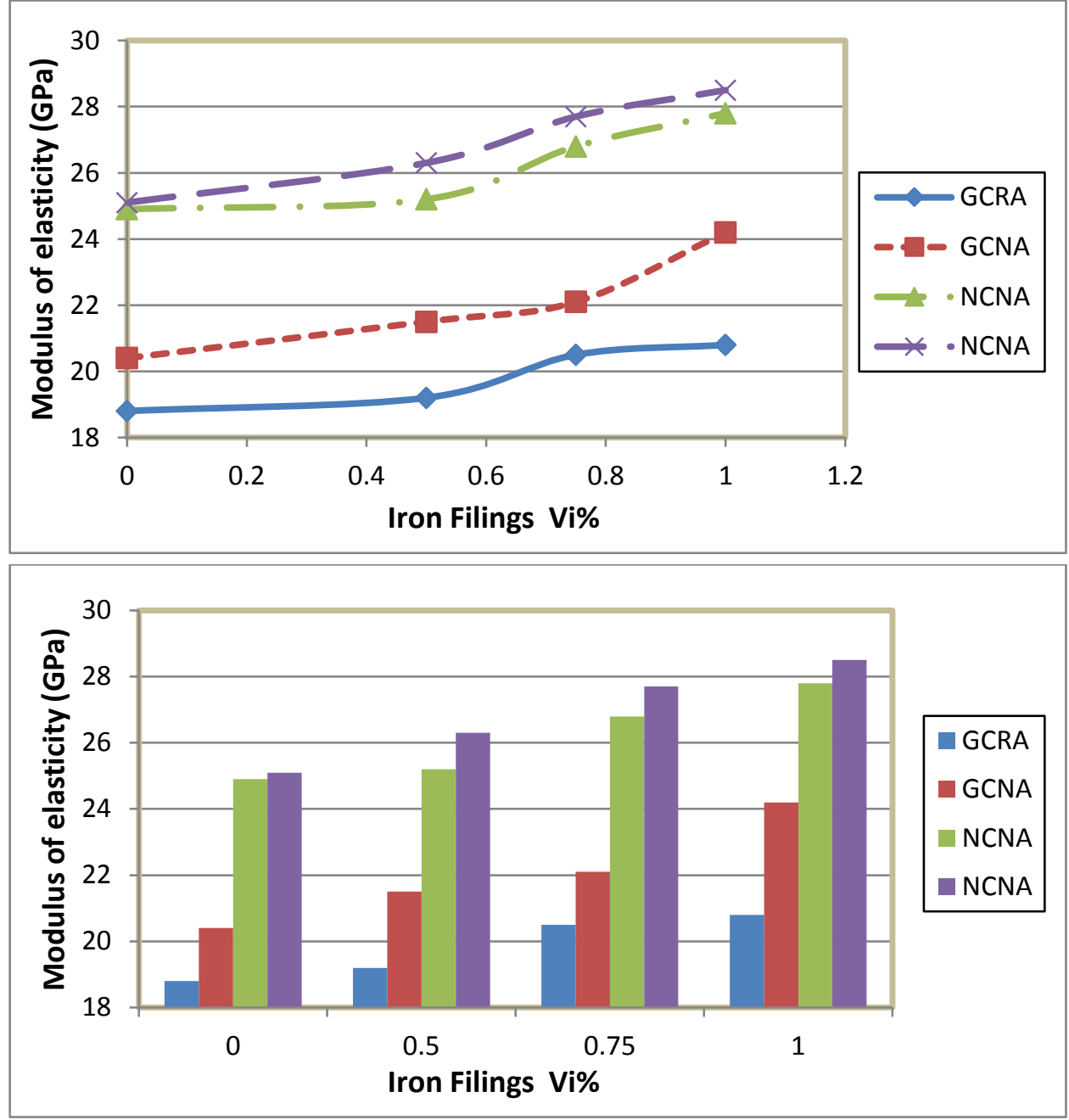

Fig. (11). Effect of iron filings on modulus of elasticity. 
Due to the high softness of iron filings, it improves the value of the concrete. It fills the voids and improves the internal structure of cement and Geopolymer paste. Due to the very low aspect ratio, the phenomenon of baking does not occur, which leads to the spread of the iron filings in the mixture and positively affect the resistance.

The roughness of the surface of the recycled concrete aggregates used and its bonding more strongly with the cement paste than for the sulphate with the smooth surface, therefore, NCRA more resistance of NCNA.

\subsection{Scanning Electron Microscope(SEM)}

An electron microscope that produces a sample image by scanning the surface specimen with a focused electron beam. The electron interacts with atoms in the sample to produce several signals containing information about the morphology and composition of the sample surface. The electron beam is scanned in a scan pattern of the frame and the position of the beam is combined with the detected signal to produce an image. SEM can achieve resolutions better than 1 nanometer. Samples can be observed in high vacuum in conventional SEM, or in variable pressure or ambient SEM under low-pressure vacuum or humidity conditions, and raised at a wide range of cryogenic temperatures or with specialized instruments [18].

By checking three samples and by types of mixtures, it has been observed from Figs. (12 and 13) that:
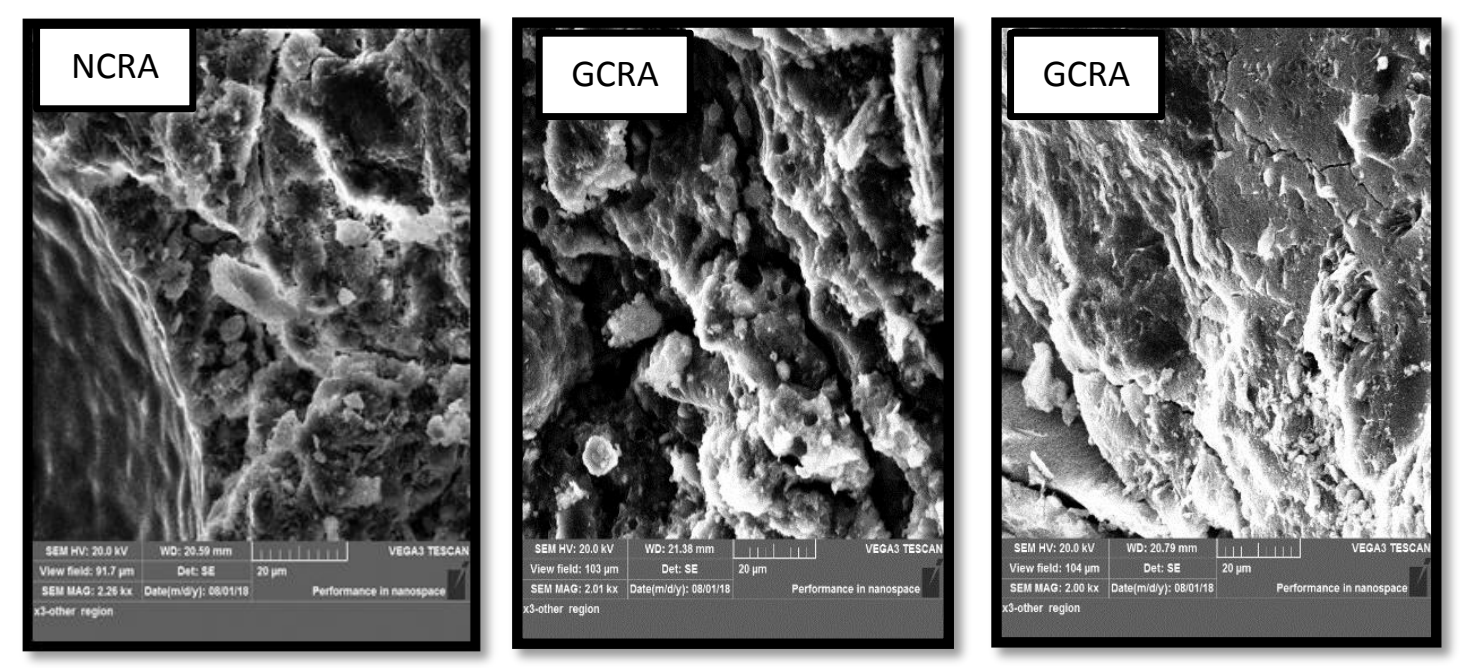

Fig. (12). SEM for $20 \mu \mathrm{m}$.
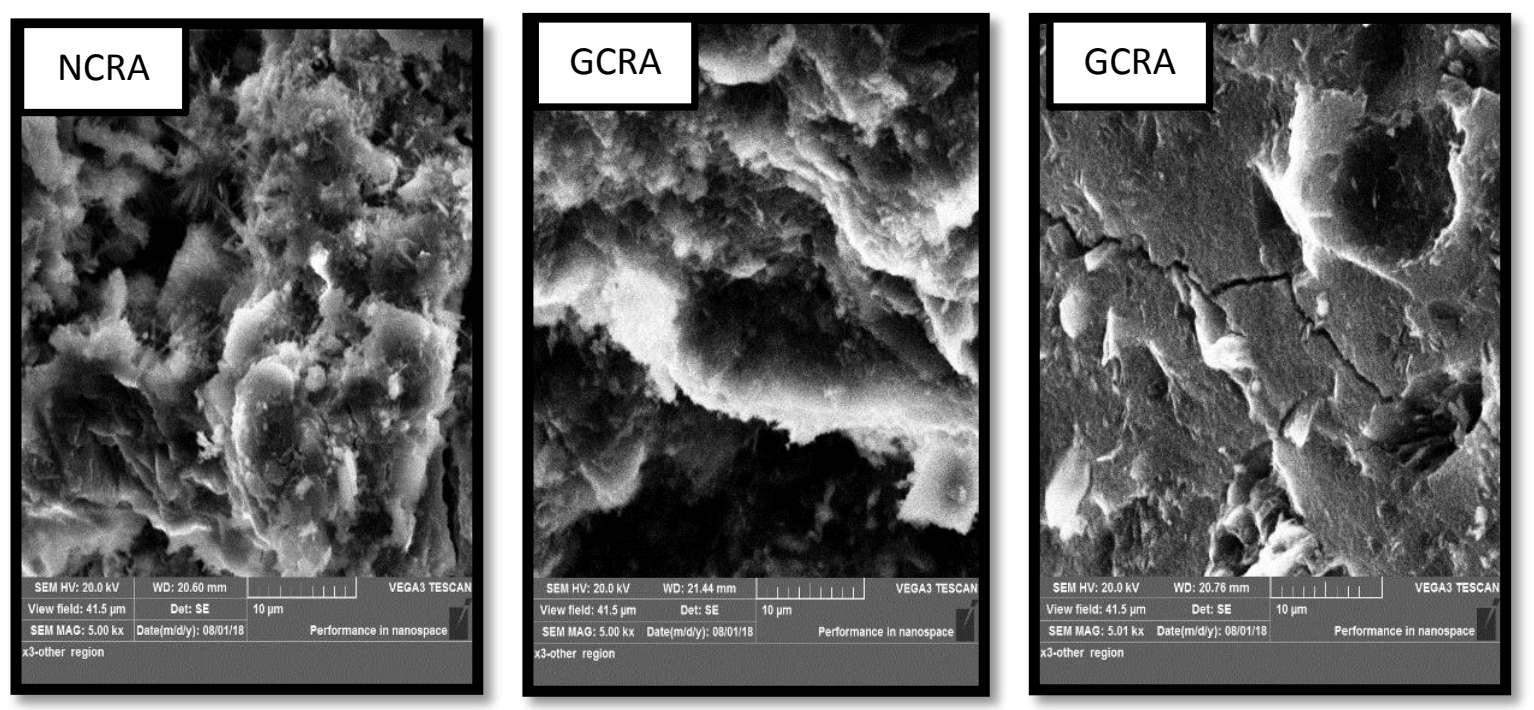

Fig. (13). SEM for $10 \mu \mathrm{m}$. 
1. The use of recycled concrete aggregate in (NCRA) with cement, the processes of clarification increase because the recycled aggregates act as a reservoir for water and help in the continuation of the processes of clarification as well as increase the strength of bonding between the aggregates and cement and increase density and over time consist of crystals form the increase of concrete resistance.

2. (GCRA) The density of the concrete is low and the presence of high gaps due to the presence of cement materials that are not ripe with recycled concrete aggregate, which lead to the absorption of the water of the mixture and hardening of the geopolymer in the first days and the absence of continuous operations of the defect, which leads to the formation of internal gaps and thus decrease density.

3. (GCNA) When replacing the recycled concrete aggregate with natural aggregates, the microscopic structure of the geopolymer improves, the gap ratio decreases and thus the density increases.

\section{CONCLUSION}

There is an improvement in the mechanical properties of the geopolymer and normal concrete by adding iron filings:

1. For geopolymer concrete with recycled concrete aggregate, the mechanical properties (compressive strength, indirect tensile strength, flexural strength and modulus of elasticity) by $10 \%, 32 \%, 42 \%$ and $11 \%$, respectively when increasing iron filings to $1 \%$.

2. For geopolymer concrete with natural aggregate, the mechanical properties (compressive strength, indirect tensile strength, modulus of rupture and modulus of elasticity) by $9 \%, 52 \%, 31 \%$ and $17 \%$ respectively when increasing iron filings to $1 \%$.

3. For normal concrete with natural aggregate, the mechanical properties (compressive strength, indirect tensile strength, modulus of rupture and modulus of elasticity) by $10 \%, 19 \%, 26 \%$ and $12 \%$ respectively when increasing iron filings to $1 \%$.

4. For normal concrete with recycled concrete aggregate, the mechanical properties (compressive strength, indirect tensile strength, modulus of rupture and modulus of elasticity) by $23 \%, 19 \%, 67 \%$ and $14 \%$ respectively when increasing iron filings to $1 \%$.

5. Due to the high softness of iron filings, it improves the value of the concrete. It fills the voids and improves the internal structure of cement and geopolymer paste. Due to the very low aspect ratio, the phenomenon of baking does not occur, which leads to the spread of the iron filings in the mixture and positively affect the resistance.

6. The use of recycled concrete aggregates is roughly similar to natural aggregates in geopolymers. Therefore, the use of recycled concrete aggregates in geopolymers is suitable for economic reasons.

7. Iron filings improve the value of the concrete, it fills the voids and improves the internal structure of cement and Geopolymer paste. Due to the very low aspect ratio, the phenomenon of baking does not occur, which leads to the spread of the iron filings in the mixture and positively affect the resistance.

8. The roughness of the surface of the recycled concrete aggregates used and its bonding more strongly with the cement paste than for the sulphate with the smooth surface.

\section{LIST OF ABBREVIATIONS}

$\begin{array}{lll}\text { FA } & = & \text { Fly Ash } \\ \text { G51 } & = & \text { Glenium } 51 \text { (High Range Water Reducing Admixture) } \\ \text { HRWRA } & = & \text { High Range Water Reducing Admixture } \\ \text { MK } & = & \text { Metakaolin } \\ \text { UHPC } & = & \text { Ultra High Performance Concrete } \\ \text { Na2SiO3 } & = & \text { Sodium Silicate } \\ \text { NaOH } & = & \text { Sodium Hydroxide } \\ \text { GGBFS } & = & \text { Ground Granulated Blast Furnace Slag } \\ \text { GPC } & = & \text { Geopolymer Concrete } \\ \text { SP } & = & \text { Super Plasticizer }\end{array}$




$\begin{array}{lll}\text { LOI } & = & \text { Loss On Ignition } \\ \text { M } & = & \text { Molarity } \\ \text { I.F } & = & \text { Iron Filings } \\ \text { SEM } & = & \text { Scanning Electron Microscope } \\ \text { RCA } & = & \text { Recycled Concrete Aggregates } \\ \text { GCNA } & = & \text { Geopolymer Concrete With Natural Aggregate } \\ \text { NCNA } & = & \text { Normal Concrete with Natural Aggregate } \\ \text { NCRA } & = & \text { Normal Concrete with Recycled Concrete Aggregate } \\ \text { GCRA } & = & \text { Geopolymer Concrete With Recycled Concrete Aggregate }\end{array}$

\section{CONSENT FOR PUBLICATION}

Not applicable.

\section{CONFLICT OF INTEREST}

The authors declare no conflict of interest, financial or otherwise.

\section{ACKNOWLEDGEMENTS}

Declared none.

\section{REFERENCES}

[1] B.V. Rangan, "Fly ash-based geopolymer concrete", Curtin University of Technology, p. 3, 2008.V.Rangan@curtin.edu.au.

[2] "PCA America's cement manufactures", Available From: https://www.cement.org/ learn/concrete-technology/ concrete-design-production/ recycled-aggregates.

[3] T. Krishnan, and R. Purushothaman, "Optimization and influence of parameter affecting the compressive strength of geopolymer concrete containing recycled concrete aggregate: Using full factorial design approach", IOP Conf. Series: Earth and Environmental Science, pp. 1-8, 2017

[4] K.C. Padmakar, B. Sarath, and C. Kumar, "An experimental study on metakaolin and GGBS based geopolymer concrete", International Journal of Civil Engineering and Technology, vol. 8, no. 1, pp. 544-557, 2017.

[5] N. Mohammed, K. Sarsam, and M. Hussien, "The influence of recycled concrete aggregate on the properties of concrete", MATEC Web of Conferences, pp. 1-7, 2018.

[6] S. Basil, Al-Shathr, S. Tareq, Al-Attar, and A. Hasan Zaid, "Optimization of geopolymer concrete based on local iraqi metakaolin", The $2^{\text {nd }}$ International Conference of Buildings, Construction and Environmental Engineering, pp. 97-100, 2015.

[7] ACI 211.1-91, "Standard practice for selecting proportions for normal, heavyweight, and mass concrete", Reported by ACI committee 211.

[8] ASTM C618, "Standard specification for coal fly ash and raw or calcined natural pozzolan for use in concrete", American society for testing and materials, 2002.

[9] IOS No.5/1984, "Portland cement", Central agency for standardization and quality control, planning council, Baghdad, IRAQ, (Translated from Arabic).

[10] IOS No.45/1984, Iraqi Specification, "Aggregate from natural sources for concrete and construction", Central agency for standardization and quality control, Baghdad, 1984.

[11] ASTM C494 "Standard specification for chemical admixtures for concrete", 2004.

[12] ASTM C143 / C143M - 10a "Standard test method for slump of hydraulic-cement concrete".

[13] ASTM C191, "Standard test methods for time of setting of hydraulic cement by vicat needle", American society for testing and materials, 2008.

[14] B.S. 1881, part 116, "Method of determination of compressive strength of concrete cubes", British Standards Institution, pp 3, 1989.

[15] ASTM C496-04, "Standard test method for splitting tensile strength for cylindrical concrete specimens", American society for testing and materials, 2004. 
[16] ASTM C78, "Standard test method for flexural strength of concrete", American society for testing and materials, 2005.

[17] ASTM C469-02, "Standard test method for static modulus of elasticity and poisson's ratio of concrete in compression", American society for testing and materials, 2002.

[18] D.J. Stokes, "Principles and practice of variable pressure environmental scanning electron microscopy (VP-ESEM)", 2008, Available From: https:// en.wikipedia.org/wiki/Scanning_electron_microscope.

(C) 2018 Alserai et al.

This is an open access article distributed under the terms of the Creative Commons Attribution 4.0 International Public License (CC-BY 4.0), a copy of which is available at: https://creativecommons.org/licenses/by/4.0/legalcode. This license permits unrestricted use, distribution, and reproduction in any medium, provided the original author and source are credited. 